\title{
Correlation and path coefficient analysis among agro-morphological and biochemical traits of okra [Abelmoschus esculentus (L.) Moench] genotypes in Ethiopia
}

\author{
Jemal MOHAMMED ${ }^{1,2}$, Wassu MOHAMMED ${ }^{3}$, Eleni SHIFERAW ${ }^{4}$
}

Received January 1, 2020; accepted March 20, 2020.

Delo je prispelo 01. januarja 2020, sprejeto 20. marca 2020

Correlation and path coefficient analysis among agro-morphological and biochemical traits of okra [Abelmoschus esculentus (L.) Moench] genotypes in Ethiopia

Abstract: Thirty six okra genotypes were evaluated for different agro-morphological and biochemical traits at Melkassa Agricultural Research Center, Ethiopia during 2018 main season using $6 \times 6$ simple lattice design. The objectives were to assess the correlation of agro-morphological and biochemical traits with fruit yield and to partition the correlation in to direct and indirect effects through path analysis. The genotypic correlation was positive and significant for fruit yield per hectare with stem diameter, plant height, leaf length, leaf width, peduncle length, fruit length, fresh fruit mass, hundred seed mass, seed yield per hectare and ash content. The phenotypic correlation was positive and significant for fruit yield per hectare with stem diameter, plant height, number of branches, leaf length, leaf width, peduncle length, fruit length, fresh fruit mass, number of fruits per plant, hundred seed mass, seed yield per hectare, ash, fat and protein content. Path coefficient analysis indicated fresh fruit mass and seed yield per hectare had positive direct effects on fruit yield per hectare at phenotypic and genotypic levels. These traits also exerted high to low positive indirect effects through other traits on fruit yield at genotypic and phenotypic level. In conclusion, this study showed the presence of association of traits with fruit yield indicating that the prime importance of these traits while selecting higher yield okra genotypes.

Key words: correlation; genotypic correlation; path analysis; phenotypic correlation
Korelacija in multipla regresijska analiza med agro-morfološkimi in biokemijskimi lastnostmi genotipov okre [Abelmoschus esculentus (L.) Moench] v Etiopiji

Izvleček: Šestintrideset genotipov okre je bilo ovrednoteno na osnovi agro-morfoloških in biokemijskih lastnosti v Melkassa Agricultural Research Center, Etiopija, v glavni rastni sezoni 2018 v nepopolnem bločnem poskusu. Predmet raziskave je bil oceniti korelacijo med agro-morfološkimi in biokemijskimi lastnostmi okre s pridelkom plodov in razdeliti korelacijo na neposredne in posredne učinke $\mathrm{z}$ multiplo regresijsko analizo. Genotipska korelacija je bila pozitivna in značilna za pridelek plodov na hektar, s premerom stebla, višino rastlin, dolžino in širino lista, dolžino plodnega peclja, dolžino plodu, svežo maso plodu, maso stotih semen, pridelkom semen na hektar in vsebnostjo pepela. Fenotipska korelacija je bila pozitivna in značilna za pridelek plodov na hektar, s premerom stebla, višino rastlin, številom stranskih poganjkov, dolžino in širino listov, dolžino plodnega peclja, dolžino plodu, svežo maso plodu, številom plodov na rastlino, maso stotih semen, pridelkom semen na hektar, vsebnostjo pepela, maščob in beljakovin. Multipla regresijska analiza je pokazala, da imata sveža masa plodov in pridelek semen na hektar pozitivni neposredni učinek na pridelek plodov na fenotipski in genotipski ravni. Te lastnosti sta izkazali tudi velike do majhne pozitivne posredne učinke skozi druge lastnosti na pridelek plodov na genotipski in fenotipski ravni. Na osnovi te raziskave lahko zaključimo, da obstaja povezava med lastnostmi in pridelkom plodov, ki so najvažnejše pri odbiranju genotipov okre z velikim pridelkom.

Ključne besede: korelacija; genotipska korelacija; multipla regresijska analiza; fenotipska korelacija

1 Crop and Horticulture Biodiversity Directorate, Ethiopian Biodiversity Institute, Addis Ababa, Ethiopia

2 Corresponding author, e-mail: jemalm781@gmail.com

3 Haramaya University, School of Plant Science, Dire Dawa, Ethiopia

4 Crop and Horticulture Biodiversity Directorate, Ethiopian Biodiversity Institute, Addis Ababa, Ethiopia 


\section{INTRODUCTION}

Okra [Abelmoschus esculentus (L.) Moench] is a member of the family Malvaceae. It originated somewhere around Ethiopia and was cultivated by the ancient Egyptians by the $12^{\text {th }}$ century BC. Its cultivation spread throughout the Middle East and North Africa (Lamont, 1999). The Nile Basin seems to have been the route by which this crop spread through North Africa, the Eastern Mediterranean, Asia, and to India. Okra reached the new world by the way of Brazil and Dutch Guinea. African slaves brought okra to North America by way of New Orleans (Bisht et al., 1995). The crop is grown in many parts of the world, especially in tropical and subtropical countries (Kumar et al., 2010). India, Nigeria, Sudan and Mali lead the production of Okra in the world (FAOSTAT, 2017).

Correlation coefficient is numerical measure which is used to find out the degree of relationship between two or more traits. The intensity of correlation between different variable is represented by $r$. The correlation coefficient, $r$ ranges from -1 to 1 . If $r$ is -1 , there is $100 \%$ correlation between two variables, but both vary in opposite direction (negative correlation). On the other hand, if $r$ is +1 , it indicates perfect correlation $(100 \%)$ where both traits vary in the same direction (positive correlation). If $\mathrm{r}=0$ there is no correlation at all between two variables, that is the two variables are independent of each other or no correlation indicates that genes concerned are located far apart on the same chromosome or they are located on different chromosomes. Also, in plant genetics and breeding studies, correlated traits are key importance because of genetic causes of correlations through pleiotropic action or developmental interactions of genes and changes brought about by a natural or artificial selection (Falconer \& Mackay, 1996; Sharma, 1998).

Path coefficient analysis partitions the correlation in to direct and indirect effects and thus may be useful in choosing the characters that have direct and indirect effects on yield (Balai et al., 2014) and also simultaneously captures the effects of intricate relationship among various traits under investigation. Therefore, this study was aimed to analyse and determine the traits having greater association with fruit yield of okra and path analysis for different agro morphological and biochemical traits in okra.

\section{MATERIAL AND METHODS}

\subsection{DESCRIPTION OF THE STUDY SITE}

The field study was conducted at Melkassa Agricul- ture Research Center, Ethiopia in 2018 main cropping season (rainy season). Melkassa is located $8^{0} 24^{\prime} 59.20^{\prime \prime} \mathrm{N}$ latitude and $39^{\circ} 19^{\prime} 15.19^{\prime \prime} \mathrm{E}$ longitude with an altitude of 1548 meter above sea level (MARC, 2008). The biochemical contents of the seeds were determined at Ethiopian Biodiversity Institute food and nutrition laboratory (total ash and crude fat), Debrezeyit Agriculture Research Center (crude fibre) and Melkassa Agriculture Research Center (total protein).

\subsection{EXPERIMENTAL MATERIALS AND DESIGN}

Total of 36 okra genotypes was used from six geographic regions (South Western, Western, North Western and Northern Ethiopia (24 landrace accession collected by Ethiopian Biodiversity Institute) one released variety and two genotypes from Humera Agriculture Research Center), nine commercial varieties (eight from India and one from USA) were included. The genotypes were planted $6 \times 6$ simple lattice design with two replications.

\subsection{DATA COLLECTION}

Data were collected for phenology traits (days to $50 \%$ emergence, days to $50 \%$ flowering and days to $90 \%$ maturity), growth and yield related traits (plant height, stem diameter, number of primary branches per stem, number of internodes, internodes length, leaf length, leaf width, peduncle length, fruit length, average fruit mass, number of tender fruits per plant, number of ridges on fruit, fruit yield per hectare, number of seeds per capsule, hundred seed mass and seed yield per hectare) and biochemical content of the seed determined (total ash, total fat, crude fibre and total protein) following the procedure of Association of Official Analytical Chemists (AOAC, 2000).

\subsection{DATA ANALYSIS}

\subsubsection{Phenotypic and genotypic correlation coeffi- cient analysis}

Phenotypic (rp) and genotypic ( $\mathrm{rg}$ ) correlations between two traits were estimated using the formula suggested by Johnson et al. (1955) and Singh \& Chaudhury (1985).

$$
r p=\frac{\sigma^{2} P x y}{\sqrt{\left(\sigma^{2} p x\right)\left(\sigma^{2} p y\right)}}
$$




$$
r g=\frac{\sigma^{2} G x y}{\sqrt{\left(\sigma^{2} g x\right)\left(\sigma^{2} g y\right)}}
$$

Where,

$\mathrm{rp}=$ Phenotypic correlation coefficient

$\mathrm{rg}=$ Genotypic correlation coefficient

$\sigma^{2} \mathrm{P} x y=$ Phenotypic covariance between variables $\mathrm{x}$ and $\mathrm{y}$

$\sigma^{2} \mathrm{G} x y=$ Genotypic covariance between variables $\mathrm{x}$ and $\mathrm{y}$

$\sigma^{2} p x=$ Phenotypic variance of variable $\mathrm{x}$

$\sigma^{2} g x=$ Genotypic variance of variable $\mathrm{x}$

$\sigma^{2} p y=$ Phenotypic variance of variable y

$\sigma^{2} g y=$ Genotypic variance of variable $y$

The coefficient of correlation at phenotypic level was tested for significance by comparing the values of correlation coefficient with tabulated $\mathrm{r}$ value at $\mathrm{g}$-2 degree of freedom, where ' $\mathrm{g}$ ' is number of genotypes. However, the coefficient of correlations at genotypic level was tested for the significance using the formula described by Robertson (1959).

$$
t=\frac{(\operatorname{rgxy})}{\operatorname{SErgxy}}
$$

The calculated " $\mathrm{t}$ " value was compared with the tabulated " $t$ " value at g-2 degree of freedom at $5 \%$ level of significance. Where, $g=$ number of genotypes, $\operatorname{rgxy}=$ genotypic correlation coefficient and SErgxy = standard error of genotypic correlation coefficient between character $\mathrm{x}$ and $\mathrm{y}$ which will be calculated as:

$$
\text { SErgxy }=\sqrt{\frac{\left(1-r^{2}\right)^{2}}{2 H^{2} x H^{2} y}}
$$

Where: $\mathrm{SE}_{\mathrm{rgxy}}=$ standard error of genotypic correlation coefficient between character $\mathrm{x}$ and $\mathrm{y}, \mathrm{H}^{2} \mathrm{x}=$ Heritability value of character $\mathrm{x}$ and $\mathrm{H}^{2} \mathrm{y}=$ heritability value of character $\mathrm{y}$.

\subsubsection{Path Coefficient Analysis}

Based on genotypic and phenotypic correlations, path coefficient analysis which refers to the estimation of direct and indirect effects of the fruit yield attributing characters (independent character) on fruit yield (de- pendent character) was calculated based on the method used by Dewey \& Lu (1959) as follows:

$$
r i j=p i j+\sum r i k p k j
$$

Where, rij $=$ mutual association between the independent character (i) and dependent character ( $j$ ) as measured by the genotypic and phenotypic correlation coefficients. Pij $=$ direct effect of the independent character (i) on the dependent variable ( $j$ ) as measured by the genotypic path coefficients, and rikpkj = Summation of components of indirect effect of a given independent character (i) on a given dependent character (j) via all other independent characters $(\mathrm{k})$.

The residual effect, which determines how the best the causal factors account for the variability of the dependent factor yield, were computed using the formula:

$$
1=P^{2} R+\Sigma p i j \text { rij }
$$

Where, $p^{2} R$ is the residual effect and $p$ ijrij is the product of direct effect of any variable and its correlation coefficient with yield. SAS 9.0 (SAS, 2004) was used for both genotypic and phenotypic correlation and path analysis.

\section{RESULT AND DISCUSSIONS}

\subsection{PHENOTYPIC AND GENOTYPIC CORRELA- TION COEFFICIENT}

\subsubsection{Phenotypic and genotypic correlations of fruit yield with other traits}

Fruit yield per hectare showed positive and significant correlations with stem diameter, plant height, leaf length, leaf width, peduncle length, fruit length, fresh fruit mass, hundred seed mass, seed yield per hectare and total ash both at the genotypic and phenotypic levels. Fruit yield per hectare had positive and significant phenotypic correlations with number of branches, number of internodes, number of fruit ridge, number of fruit per plant, total fat and protein content and these traits had positive but nonsignificant genotypic correlations with fruit yield per hectare (Table 1).The presence of significant correlation of these traits with fruit yield per hectare both at genotypic and phenotypic levels indicated prime importance of these traits in selection program to identify okra genotypes with high fruit and seed yield. This result is in agreement with Muluken et al. (2015), Mihretu et al. (2014), Saitwal et al. (2011) and Dhankhar \& Dhankhar (2002). 


\subsubsection{Correlation coefficients among other traits}

Day to $50 \%$ flowering with days to maturity had significant correlation at phenotypic and genotypic levels. Days to $50 \%$ emergence had a significant association with days to $50 \%$ flowering at genotypic levels, but days to $50 \%$ emergence had positive and nonsignificant correlations with day to $50 \%$ flowering at phenotypic level and with days to maturity both at phenotypic and genotypic levels. Days to $50 \%$ flowering and days to maturity showed positive and significant associations with stem diameter and number of internodes at phenotypic and genotypic levels. Days to $50 \%$ emergence and days to maturity had positive and significant correlations with peduncle length both at phenotypic and genotypic levels (Table 1). This suggested that the selection of genotypes for phenology traits (days to seedlings emergence, flowering and maturity) may not affect the selection of genotypes for plant growth performances. Muluken et al. (2015) also indicated that a positive correlation between traits allows the selection of genotypes simultaneously for the correlated traits.

Fozia (2018) reported that the phenology traits (days to emergence, days to $50 \%$ flowering and days to maturity) showed significant association among them both at genotypic and phenotypic levels except the genotypic correlation between days to emergence and days to maturity was positive but nonsignificant. She also observed genotypic correlation of phenology traits with growth traits of okra was nonsignificant except the genotypic correlation of days to emergence with number of internodes per plant and days to maturity with stem diameter showed negative and positive significant genotypic association, respectively.

The genotypic and phenotypic correlations among stem diameter, plant height and number of branches were positive and significant. These traits also had positive and significant correlations at genotypic and phenotypic levels with other growth traits viz., number of internodes, internode length, leaf length, leaf width and peduncle length except stem diameter with internode length at genotypic and phenotypic levels and plant height with peduncle length at genotypic and phenotypic level showed nonsignificant associations. Leaf length with leaf width; leaf length and leaf width with peduncle length had positive and significant correlations at genotypic and phenotypic levels. Number of internodes with leaf length, leaf width and peduncle length; internode length with leaf length showed positive and significant phenotypic correlations.

Stem diameter and plant height with hundred seed mass and seed yield per hectare; stem diameter with fresh fruit mass; plant height with number of fruits per plant had positive and significant genotypic and phenotypic correlations. In addition, plant height and fresh fruit mass showed positive and significant phenotypic correlation. Leaf width and peduncle length with fruit length, fresh fruit mass, number of fruits per plant, hundred seed mass and seed yield per hectare had positive and significant genotypic and phenotypic correlations. Number of internodes and internode length with seed yield per hectare showed positive and significant associations at genotypic and phenotypic levels. The results indicated that the selection of genotypes for one of or more of growth traits particularly stem diameter and plant height is a simultaneous selection for other growth traits and most of the fruit yield components. Ehab et al. (2013) also, indicated that the selection on the basis of any of the significantly positive inter-related characters was expected to give a desired correlated response in other characters.

Fruit length with fresh fruit mass and hundred seed mass had positive and significant correlation at genotypic and phenotypic level. However, fruit length had positive and nonsignificant correlation with seed per capsule at genotypic and phenotypic level. Fresh fruit mass had positive and significant correlation with number of fruit ridge at genotypic and phenotypic level. Number of fruit ridge with number of fruits per plant had negative and significant correlation at phenotypic level. Therefore, it is important to give attention to number of ridges in the process of the selection of okra genotypes for high number of fruits per plant. Akinyele \& Osekita, (2006); Nwangburuka et al. (2012) and Ahiakpa et al. (2012) also suggested that negative association of traits was difficult or practically impossible to improve through simultaneous selection of those traits. The sign of genetic correlations between two characters can either facilitate or impede selection progress and $\mathrm{r}=0$ or nonsignificant carries the implication of no correlation between the two characters (Singh \& Chaudhary, 1977; Falconer \& Mackay, 1996; Sharma, 1998).

The other important yield of okra is its seed yield which can be used for different purpose. The seed can be used as a substitute for coffee and the oil content of the seed is quite high at about $40 \%$ (Anwar et al., 2011). The correlation of seed yield had positive and significant correlation coefficient with stem diameter, plant height, number of internods, internod length, leaf length, leaf width, peduncle length, number of fruits per plant and fruit yield per hectare at genotypic and phenotypic level. It had also positive and nonsignificant correlation with fruit length both at genotypic and phenotypic level (Table 1). Fozia (2018) reported that seed yield per plant had positive and significant correlation with plant height, stem diameter, branch, number of internodes, internod 


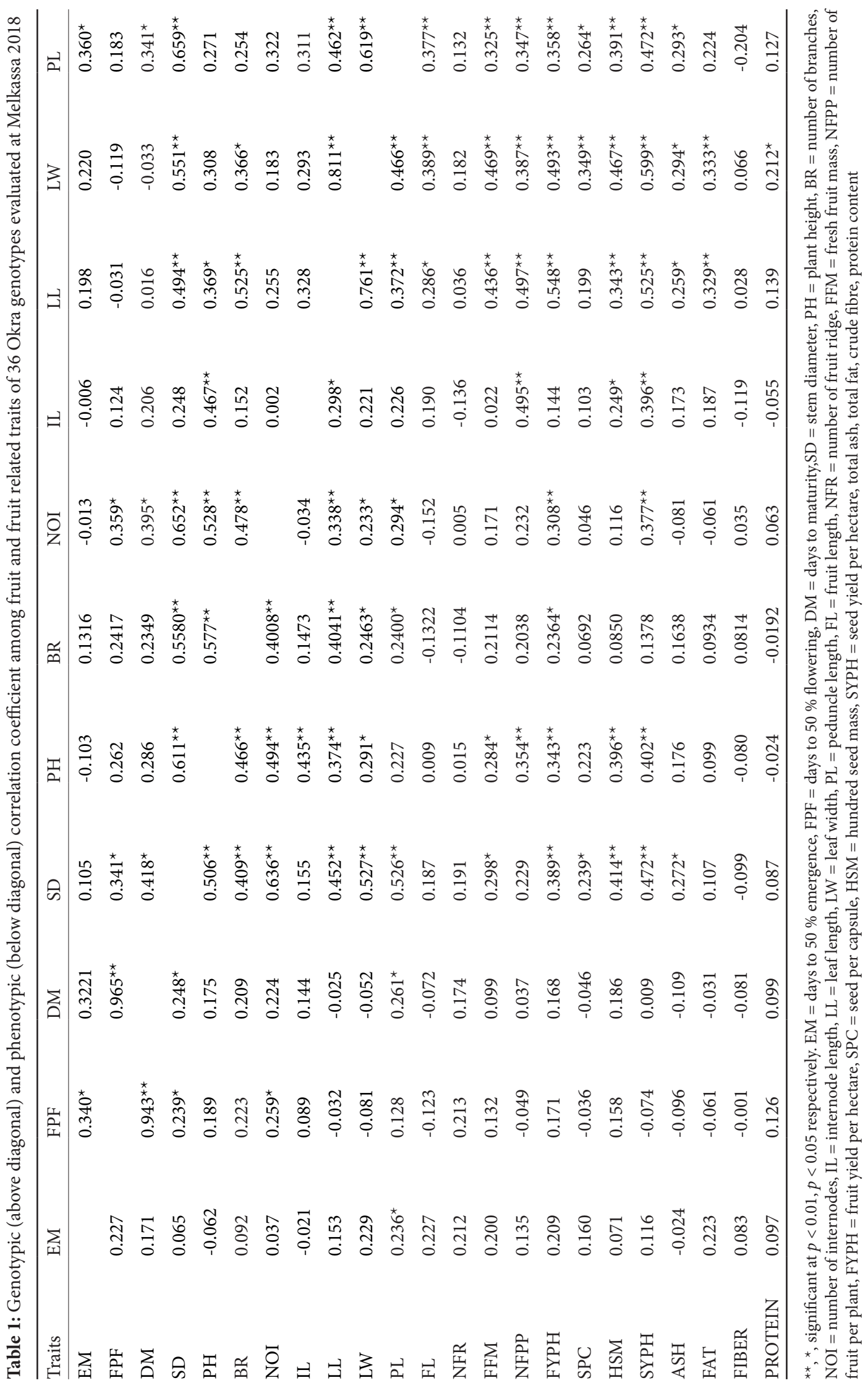




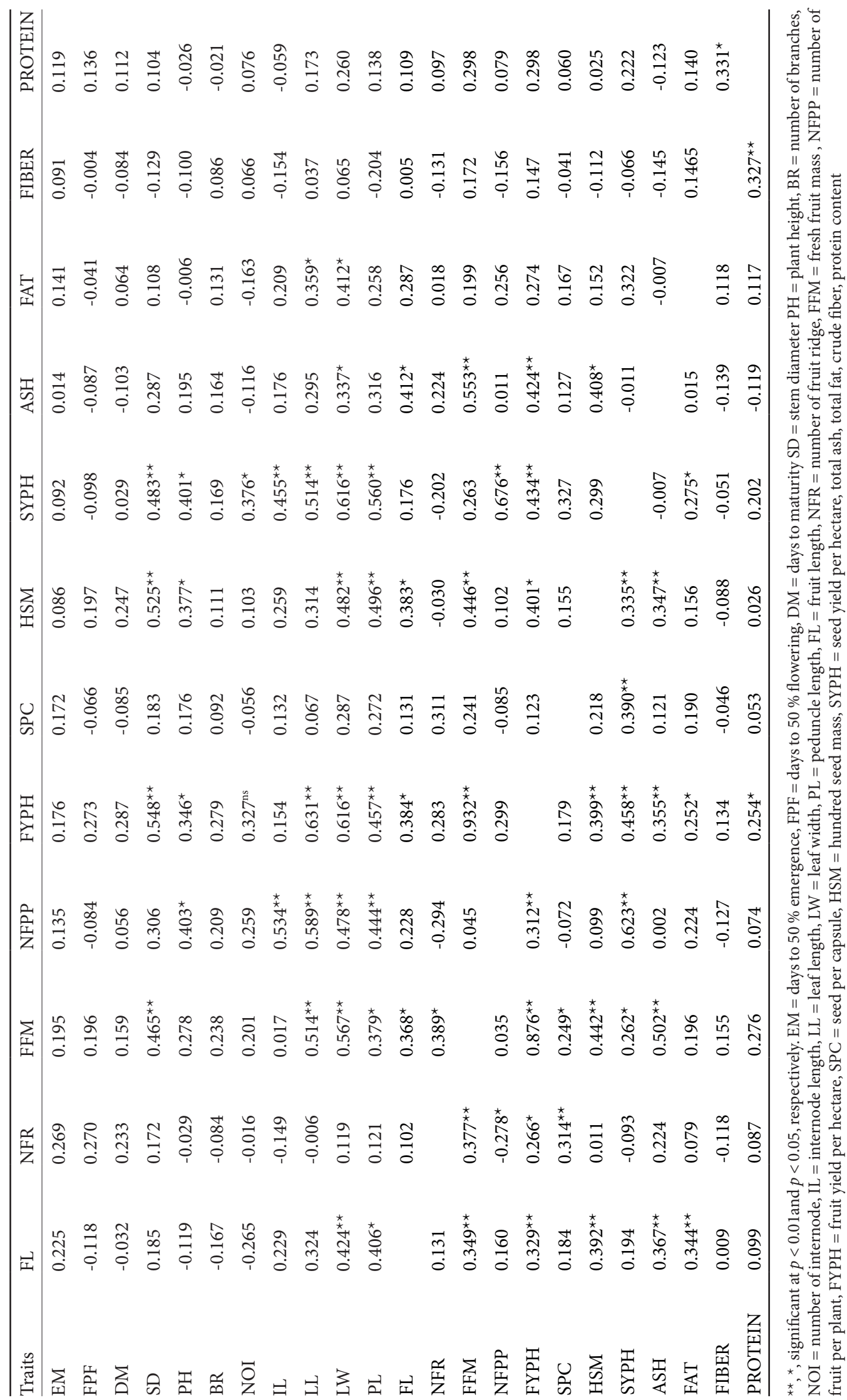


length, number of fruit ridge, number of seed per capsule and hundred seed mass.

The genotypic and phenotypic correlation coefficient showed crude fibre with total protein was the only positive and significant correlation among biochemical traits at genotypic and phenotypic level. However, ash with leaf width, fruit length, fresh fruit mass and hundred seed mass; crude fat with leaf length and width had positive and significant correlation at genotypic and phenotypic level. Similar result had reported by Prasath et al. (2017) crude fibre content exhibited positive and significant correlation with protein content.

\subsection{PATH ANALYSIS}

\subsubsection{Genotypic path coefficient analysis of fruit yield with other traits}

Stem diameter, leaf length, leaf width, peduncle length, fruit fresh mass, seed yield per hectare, and ash content had positive and highly significant $(p<0.01)$ correlation, and plant height, fruit length and hundred seed mass had positive and significant $(p<0.05)$ correlation with fruit yield per hectare. Majority of these traits also exerted positive direct effect on fruit yield per hectare. Lenka \& Mishra (1973) rated the direct and indirect effects into negligible (0.00-0.09), low (0.10-0.19), moderate (0.20$0.29)$, high (0.30-1.00) and very high (> 1.00). Accordingly, fresh fruit mass (0.901) had positive and high direct effect on yield while leaf length (0.219) and seed yield per hectare $(0.146)$ exerted positive moderate and low direct effect on fruit yield per hectare, respectively.

In addition, fresh fruit mass had exerted high positive indirect effect on fruit yield via stem diameter, leaf length, leaf width, peduncle length, fruit length, hundred seed mass and ash content. Fresh fruit mass also had moderate positive indirect effect on fruit yield via seed yield per hectare and plant height. This indicated that the positive and significant genotypic correlations of traits with fruit yield were due to the direct effects of the traits on yield. Therefore, it is possible to suggest that the traits could be used for indirect selection of genotypes for high fruit yield. Prasath et al. (2017), Rambabu et al. (2019) the direct effect of traits on fruit yield per hectare favours yield improvement through selection. These suggested that indirect selection based on these traits will be effective in yield improvement.

Fruit length (0.088), stem diameter (0.078), peduncle length (0.032), plant height (0.019) had positive and negligible direct effects on fruit yield. Whereas, leaf width $(-0.197)$ and ash content $(-0.116)$ exerted low negative direct effects on fruit yield. Hundred seeds mass (-0.069) negative but negligible direct effects on fruit yield. If the trait has positive correlation and the direct effect of the trait is negative or negligible, the positive correlation of the trait is because of the indirect effects through other traits. In such situation, the indirect causal factors/traits are to be considered simultaneously for selection (Singh \& Chaudhary, 1977).

The residual effect in the present genotypic path study was 0.058 (Table 2 ) showing that $94.19 \%$ of the variability in the fruit yield per hectare was explained by the component factors. The remaining $5.8 \%$ is explained by other traits not considered in this study.

\subsubsection{Phenotypic path coefficient analysis of fruit yield with other traits}

The phenotypic correlation coefficient computed between fruit yield per hectare and other traits showed the presence of significant association with stem diameter, plant height, namber of branches, number of internods, leaf length, peduncle length, fruit length, fresh fruit mass, number of fruit per plant, hundred seed mass, seed yield per hectare, ash, fat and protein content. This implies the importance of partitioning the correlation coefficients into direct and indirect effects on fruit yield per hectare, so as to determine the selection criteria for fruit yield improvement in okra.

Fresh fruit mass had high (0.911) positive direct effect on fruit yield followed by number of fruits per plant (0.257) which exerted a moderate direct effect on fruit yield per hectare. Stem diameter (0.134), leaf length $(0.124)$ and seed yield per hectare $(0.106)$ had low direct effect on fruit yield per hectare. Number of internods, fruit length, number of fruit ridge, hundred seed mass and fat content had positive and negligible direct effect on fruit yield per hectare. On the other hand, plant height, number of branches, peduncle length, ash and protein content had exerted negative and negligible direct effect on fruit yield per hectare (Table 3). Leaf width had negative and low direct effect on fruit yield per hectare.

On other hand, fresh fruit mass had exerted high and positive indirect effect on fruit yield via leaf length, leaf width, fruit length, number of fruit ridge, hundred seed mass and ash content. It had also exerted moderate and positive indirect effect on fruit yield through stem diameter, plant height, peduncle length, seed yield per hectare and protein content. In this study, the results of phenotypic path coefficient analysis showed that fresh fruit mass followed by number of fruits per plant, seed yield per hectare, stem diameter and leaf width could be used as selection criteria for high fruit yield per hectare in okra genotypes. Besides positive and highly significant correlation of these traits with fruit yield per hectare, the traits had high, mod- 


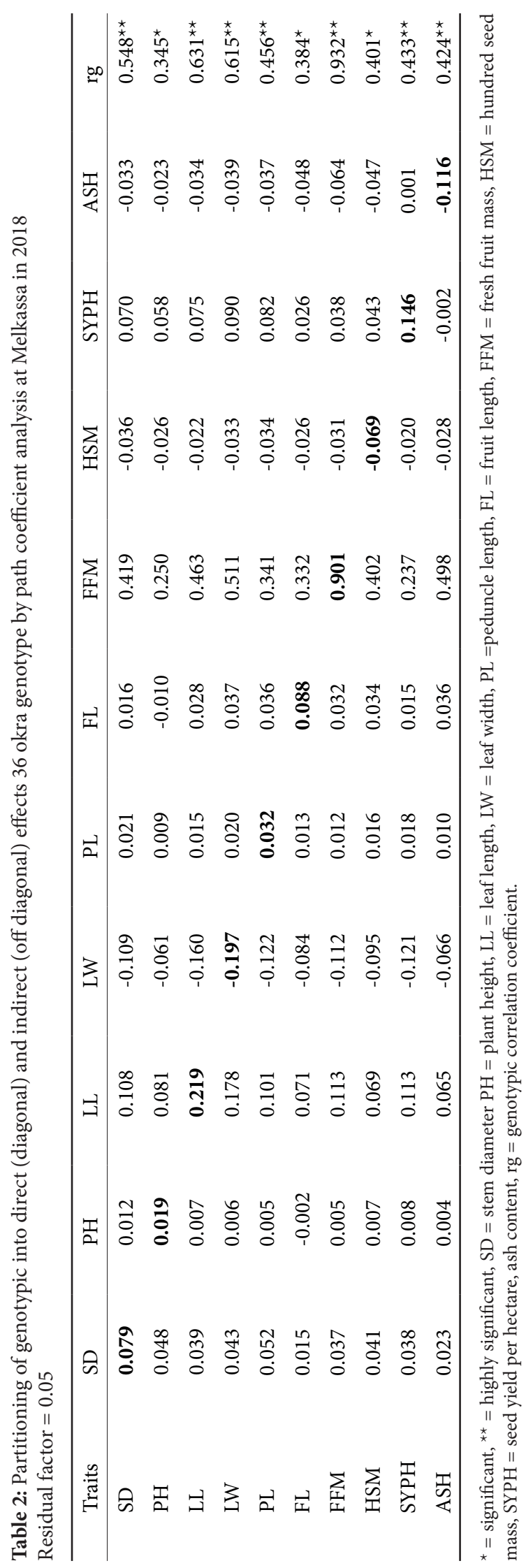




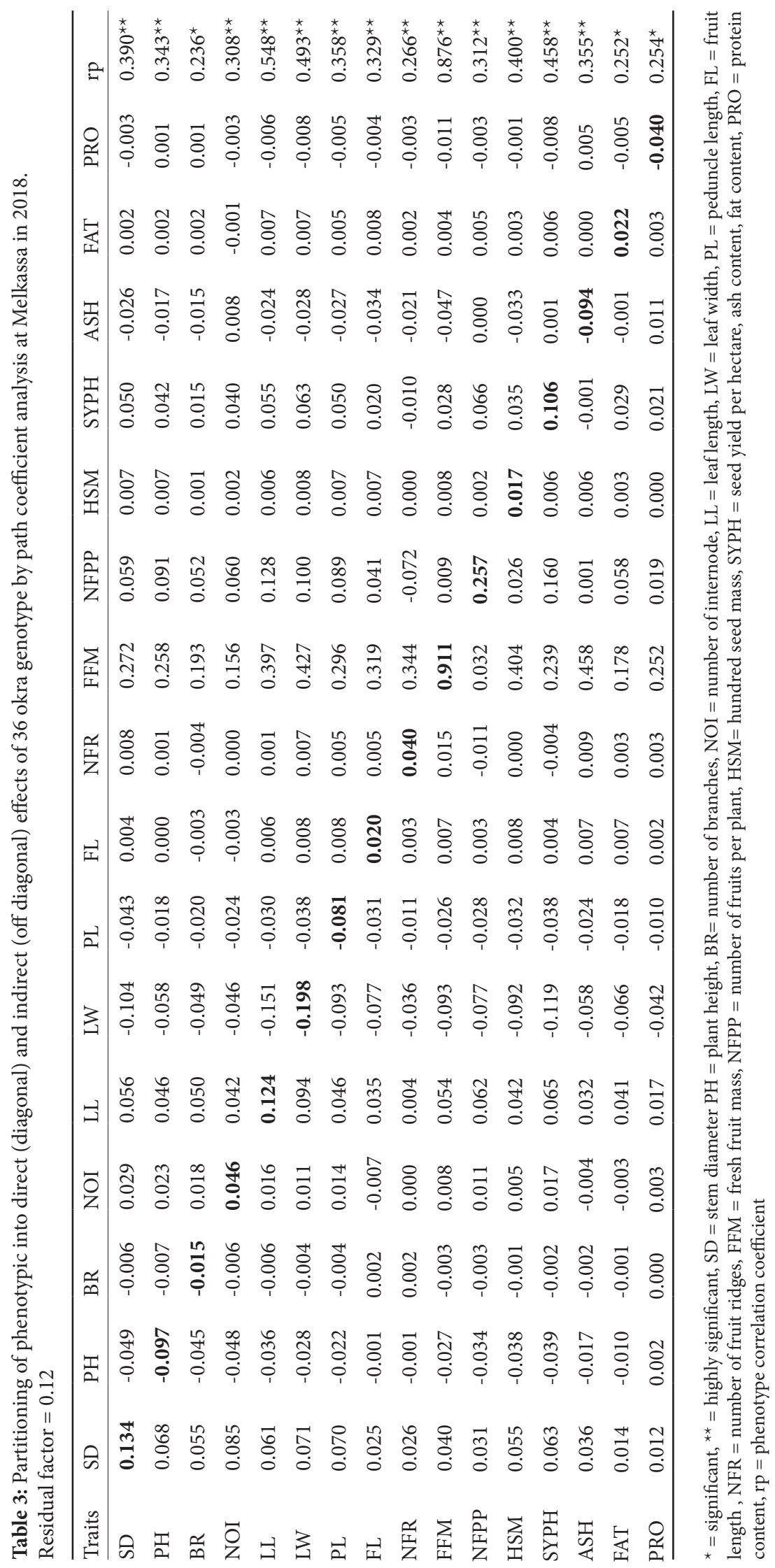


erate and low positive direct effect. If the correlation coefficient between causal factor and the effect is almost equal to its direct effect, the correlation explains the true relationship and the direct selection through these traits will be effective (Singh \& Chaudhary, 1977). Kumar \& Reddy (2016) reported similar result with the present result that, fruit length had positive and negligible direct effect on fruit yield.

The residual effect from phenotypic path analysis was 0.12 (Table 3), indicating that all the traits included in the study explained high percentage of variation $(88.27 \%$ ) in fruit yield per hectare in okra and other factors not included in the study can explain $11.73 \%$. The residual effect determines how much best the causal factors or dependent variables account for the variability of dependent variable (Singh \& Chaudhary, 1977; Dabholkar, 1992).

\section{CONCLUSION}

The genotypic correlation coefficient between fruit yield per hectare and most of the other traits was positive and significant except days to $50 \%$ emergence, days to $50 \%$ flowering, days to maturity, number of branches, number of internods, number of fruit ridge, number of fruits per plant, seed per capsule, fat, fibre and protein content. The phenotypic correlation coefficient between fruit yield per hectare and all traits was positive and significant except days to $50 \%$ emergence, days to $50 \%$ flowering, days to maturity, internods length, seed per capsule and fibre content. Among the traits; fresh fruit mass and seed yield per hectare had positive direct effects on fruit yield per hectare at phenotypic and genotypic levels. Number of fruit per plant had also a moderate direct effect on fruit yield per plant at phenotype level. These traits also exerted high to low positive indirect effects through other traits on fruit yield at genotypic and phenotypic level. Therefore, these traits will have practical importance in selection of okra genotypes for high fruit yield per hectare.

\section{ACKNOWLEDGEMENT}

The authors would like to acknowledge Africa Center of Excellence for Climate Smart Agriculture and Biodiversity Conservation, Haramaya University for providing of research fund.

\section{REFERENCE}

Ahiakpa, J.K. (2012). Characterization of twenty-nine (29) ac- cessions of okra [Abelmoschus Spp(L.) Moench] in Ghana. Master of Philosophy, University of Ghana, Ghana.

Akinyele, B. O., \& Osekita, O. S. (2006). Correlation and path coefficient analyses of seed yield attributes in okra (Abelmoschus esculentus (L.) Moench). African Journal of Biotechnology, 5(14), 1330-1336.

Anwar, F., Rashid, U., Mahmood, Z., Iqbal, T., \& Sherazi, T. H. (2011). Inter-varietal variation in the composition of okra (Hibiscus esculentus L.) seed oil. Pakistan Journal of Botany, 43(1), 271-280.

AOAC (Association of Official Analytical Chemists). 2000. Official methods of analysis (vol.2 $17^{\text {th }}$ edition) of AOAC International. Washington, DC, USA. Official methods 925.09, 923.03, 962.09, 4.5.01 and.6.25.

Balai, T. C., Maurya, I. B., Verma, S., \& Kumar, N. (2014). Correlation and path analysis in genotypes of okra [Abelmoschus esculentus (L.) Moench]. The Bioscan, 9(2), 799-802.

Bisht, I. S., Mahajan, R. K., \& Rana, R. S. (1995). Genetic diversity in South Asian okra (Abelmoschus esculentus) germplasm collection. Annals of applied biology, 126(3), 539-550. https://doi.org/10.1111/j.1744-7348.1995.tb05388.x

Das, S., Chattopadhyay, A., Chattopadhyay, S. B., Dutta, S., \& Hazra, P. (2012). Characterization of okra germplasm and their genetic divergence in the gangetic alluvium of eastern India. Vegetos an International Journal of Plant Research, 25(2), 86-94.

Dewey, D. R., \& Lu, K. (1959). A Correlation and Path-Coefficient Analysis of Components of Crested Wheatgrass Seed Production 1. Agronomy Journal, 51(9), 515-518. https:// doi.org/10.2134/agronj1959.00021962005100090002x

Dhankhar, B. S., \& Dhankhar, S. K. (2002). Genetic variability, correlation and path analysis in okra [Abelmoschus esculentus (L.) Moench]. Vegetable Science, 29(1), 63-65.

Ehab. AA. I., Mohamed.Y. A. \& Ali M. M. 2013. Genetic behaviour of families selected from some local okra [Abelmoschus esculentus(L.) Moench] populations in Egypt. Plant Breeding Biotechnology, 1(4), 396-405. https://doi.org/10.9787/ PBB.2013.1.4.396

Ibrahim, E. A. A., Abed, M. Y., \& Moghazy, A. M. (2013). Genetic Behavior of Families Selected from Some Local Okra (Abelmoschus esculentus L. Moench) Populations in Egypt. Plant Breeding and Biotechnology, 1(4), 396-405. https://doi.org/10.9787/PBB.2013.1.4.396

Falconer, D.S. \& Mackay, T.F.C. (1996). An introduction to quanitative genetic. Ed, 4.Hall London.

FAOSTAT. 2017. Food and Agricultural Organisation of the United Nations. On-line and Multilingual Database, http:// faostat.fao.org/faostat/.

Fozia Yimam. 2018. Genetic diversity and association of seed yield and related traits of Okra [Abelmoschus esculentus (L.) Moench] in Ethiopia. MSc thesis, Haramaya University, Haramaya, Ethiopia.

Gatti, I., Anido, F. L., Vanina, C., Asprelli, P., \& Country, E. (2005). Heritability and expected selection response for yield traits in blanched asparagus. Genetics and Molecular Research, 4(1), 67-73.

Johnson, R. A., \& Wichern, D. W. (1992). The Bonferroni method of multiple comparisons. Applied Multivariate Statistical Analysis. New York: Prentice-Hall International Inc, 9. 
Kumar, S., Dagnoko, S., Haougui, A., Ratnadass, A., Pasternak, N., \& Kouame, C. (2010). Okra (Abelmoschus spp.) in West and Central Africa: Potential and progress on its improvement. African Journal of Agricultural Research, 5(25), 35903598.

Kumar, S., \& Reddy, M. T. (2016). Correlation and path coefficient analysis for yield and its components in okra (Abelmoschus esculentus (L.) Moench). Advances in Agricultural Science, 4(1), 72-83.

Lamont, W.J. (1999). Okra A versatile vegetable crop. HortTechnology, 9(2), 179-184. https://doi.org/10.21273/HORTTECH.9.2.179

Lenka, D., \&Misra, B. (1973). Path-coefficient analysis of yield in rice varieties. Indian journal of agricultural sciences, 43(4), 376-379.

MARC (Melkassa Agricultural Research Center). (2008). Ethiopian Institute of Agricultural Research, Center Profile, Melkassa, Ethiopia.

Mihretu Yonas, Weyessa Garedew \& Adugna Debela, (2014). Multivariate analysis among Okra [Abelmoschus esculentus (L.) Moench] collection in South Western Ethiopia. Journal of Plant Sciences, 9, 43-50. https://doi.org/10.3923/ jps.2014.43.50

Muluken Demelie, Wassu Mohamed \& Endale Gebre. (2015). Genetic Diversity of Ethiopian Okra Collections through Multivariate Analysis at Werer, Rift Valley of Ethiopia. The International Journal of Science and Technology, 3(8), 186.

Nwangburuka, C. C., Kehinde, O. B., Ojo, D. K., Denton, O. A., \& Popoola, A. R. (2011). Morphological classification of genetic diversity in cultivated okra, Abelmoschus esculentus (L) Moench using principal component analysis (PCA) and single linkage cluster analysis (SLCA). African Journal of Biotechnology, 10 (54), 11165-11172. https://doi.org/10.5897/ AJB11.285

Prasath, G., Reddy, K. R., \& Saidaiah, P. (2017). Correlation and Path Coefficient Analysis of Fruits Yield and Yield Attributes in Okra [Abelmoschus esculentus (L.) Moench]. International Journal ofCurrent Microbiolial and Applied Science, 6(3), 463-472. https://doi.org/10.20546/ijcmas.2017.603.054
Reddy, M. T., Babu, K. H., Ganesh, M., Begum, H., Reddy, R. S. K., \& Babu, J. D. (2013). Exploitation of hybrid vigour for yield and its components in okra [Abelmoschus esculentus (L.) Moench]. American Journal of Agriculture Science and Technology, 1, 1-17. https://doi.org/10.7726/ajast.2013.1001

Robertson, A. (1959). The sampling variance of the genetic correlation coefficient. Biometrics, 15(3): 469-485. https://doi. org/10.2307/2527750

SAS Institute. (2004). SAS /STAT Guide for personal computers, version 9.0 editions. SAS Institute Inc. Cary, NC, USA.

Saitwal, Y. S., Solanke, S. P., Kalalbandi, B. M., Kale, S. A., \& Mendhe, S. T. (2011). Study on yield and quality of okra [Abelmoschus esculentus (L.) Moench] hybrids. Asian Journal of Horticulture, 6(1), 11-12.

Sharma, J.R., (1998). Statistical and Biometrical Techniques in Plant Breeding. New Age International (P) Limited Publishers, New Delhi. Pp 432.

Siesmonsma, J.S. (1991). International Crop Network Series. Report of an international workshop on okra genetic resources. IBPGR, Rome. 5, 52-68.

Singh, R.K. and Chaudhary. (1977). Biometrical methods in quantitative genetic analysis. Kalyani Publishers, New Delhi-Ludhiana, India.

Somashekhar, G., Mohankumar, H.D. and Salimath, P.M. (2011). Genetic analysis of association studies in segregating population of okra. Karnataka Journal of Agricultural Science. 24(4), 432-435.

Thakur, S. K., \& Sirohi, A. (2009). Correlation and path coefficient analysis in chickpea (Cicer arietinum L.) under different seasons. Legume Research, 32(1), 1-6.

Thirupathi Reddy, M., Hari Babu, K., Ganesh, M., Chandrasekhar Reddy, K., Begum, H., Purushothama Reddy, B. and Narshimulu, G. (2012). Genetic variability analysis for the selection of elite genotypes based on pod yield and quality from the germplasm of okra [Abelmoschus esculentus (L.) Moench]. Journal of Agriculture and Technology, 8(2), 639-655. 